EPRA International Journal of Economic and Business Review-Peer Reviewed Journal

Volume - 9, Issue - 9, September 2021 | e-ISSN: 2347 - 9671| p- ISSN: 2349 - 0187

\title{
IMPORTANCE OF FINANCIAL MANAGEMENT FOR THE PROPER FUNCTIONING OF AN ENTERPRISE WITH SPECIAL REFERENCE TO THE MICRO AND SMALL ENTERPRISES (MSES) OF MANIPUR
}

\author{
Jangkholam $^{1}$, A. Rajmani Singh ${ }^{2}$ \\ ${ }^{1}$ Research Scholar, Department of Commerce, Manipur University \\ ${ }^{2}$ Professor, Department of Commerce, Manipur University
}

\begin{abstract}
DOI No: $10.36713 /$ epra8394

Article DOI URL: https://doi.org/10.36713/epra8394

Micro and Small enterprises is a very important segment that continues to contribute enormously for the economic development of the country and to the state of Manipur in particular. The success and failure of these enterprises depends a lot on the efficient management of its financial resources. Working capital management which is very much a part of the financial management is also a key factor as the functioning of most of these enterprises depend mainly on their working capital. This paper therefore attempts to study the financial management practices followed by the Micro and Small Enterprises (MSEs) in Manipur and to make an awareness about the importance of financial management practices in their business conduct. For the purpose of the study both primary and secondary data are used. Secondary data were collected from the related available literature like books, articles, magazines, MSME annual report, directory of MSME Manipur, etc. Primary data is obtained by distributing structured questionnaire to the owner/manager of the sample enterprises.

The results of the study revealed that the financial management practices followed by the Micro and Small enterprises in Manipur are only fire-fighting in nature and no standardised rules or procedures are followed in managing their finance. The study suggested that a standardised financial management practices should be adopted by these enterprises which will enable them to measure and compare their performances.
\end{abstract}

KEYWORDS: Financial management, Micro and Small Enterprises (MSEs), Manipur.

\section{INTRODUCTION}

Micro Small and Medium Enterprises (MSMEs) play a very important role in the economic development of a country. MSMEs are capable of creating jobs with small amount of capital and in dispersed locations which makes it attractive to policy makers.

The sector constitutes the second largest employment provider next to the agricultural sector. World over, half to two-thirds of all businesses are MSMEs and in many regions this proportion is much higher.
(Lalhriatchhungi \& Prasain, 2017). The sector account for a major share of production and export. It helps the Indian economy tremendously by providing large employment opportunities, industrializing the rural and backward areas, bringing an equitable distribution of national income and wealth and also contributing to the socio-economic development of the country. The sector also contributed to the GDP of the country. Effective utilisation of locally available resources, lower investment requirements, operational flexibility and high rate of innovations are the advantages of the MSME sector. The 
government has extended various kinds of help to the MSMEs for their development and betterment. The Government passed the MSME Development Act, 2006 after realising the importance and contribution the MSME made to the economy. Various committees have been formed and also various research have been conducted for the improvement of the MSMEs. However, the sector continues to face various problems and hurdles which include obtaining the required finance, problems of rawmaterials, problems of inadequate accounting practices, etc. Among the various problems faced by the MSMEs, lack of proper financial management is a very serious problem of the MSMEs as their survival and success depends largely on the proper management of their financial resources. Finance is regarded as the lifeblood of a business. Finance is needed at every stage of the business development. The continuity and success of any form of business largely depend on the way they managed their finance. There is therefore a need for financial discipline and efficient management of financial resources for the success of a business.

According to the MSME Development Act, 2006, an enterprise engaged in the manufacturing and production of goods whose investment in plant and machinery does not exceed twenty-five lakh rupees is termed as micro enterprises, exceeds twenty-five lakh rupees but does not exceed five crore rupees is termed as small enterprises and exceeds five crore rupees but does not exceed ten crore rupees is termed as medium enterprises. But in the case of enterprises engaged in providing or rendering of services, the investment in equipment does not exceed ten lakh rupees is termed as micro enterprises, exceeds ten lakh rupees but does not exceed two crore rupees is termed as small enterprises and exceeds two crore rupees but does not exceed five crore rupees is termed as medium enterprises. (MSME Development Act 2006).

According to the $\mathbf{7 3}^{\text {rd }}$ round of the National Sample Survey, during the year 2015-16 there are 633.33 lakh enterprises in the country with a share of $29.20 \%$ to the GDP of the country. Out of the total MSMEs, 630.52 lakhs $(99 \%)$ are Micro enterprises, 3.31 lakh $(0.52 \%)$ are Small while 0.05 lakh $(0.01 \%)$ are medium enterprises. The MSME sector create 12.10 crore jobs where the Micro sector with 630.52 lakh estimated enterprises provides employment to 1076.19 lakh persons, which accounts for around $97 \%$ of total employment in the sector. Small sector with 3.31 lakh and Medium sector with 0.05 lakh estimated MSMEs provides employment to 31.95 lakh $(2.88 \%)$ and 1.75 lakh $(0.16 \%)$ persons of total employment in MSME sector, respectively. (MSME Annual report 2018-19).

The entire eight North-Eastern states collectively have 4.24 lakh MSMEs, which provides an employment generation of about 13.27 lakh people, as against 214.38 lakh enterprises at the national level that provides employment to 501.93 lakh people, which reveals that it is comparatively low at the national level. The units set up under PMEGP stood at 13\% (2015-16), as for MSME, it stood at $17 \%$ (2015-16), and KVIC provided employment to 9.56 lakh artisans (2012). In the context of Manipur, many investors or fund providers like NABARD, NEDFI, SIDBI, IDBI, DIC, KVI Board, KVIC and various Commercial Banks are putting a lot of efforts to help established successful SSIs in various fields. (Ratan, Rajkumar and Meetei, 2019).

The role of MSMEs in the development of the state of Manipur is very important. As on 2015 there were 1078 registered (EM-II filed) MSMEs in Manipur. The total investment in plant and machinery made by these units constitutes Rs. 108.55 crore. The production value (i.e. value of goods and services produced) constitute Rs. 427.9 crore and provide employment to 11,798. Among the MSMEs in Manipur, the Micro and small enterprises contributed the maximum in terms of units, employment and also production value.

\section{STATEMENT OF THE PROBLEM}

The MSME sector has contributed to the Indian economy by providing employment opportunities to a large section of the population. This sector utilized locally available resources, using their creativity and innovation. The government have extended various kind of help to support this sector. However, in spite of all the helps extended to them by the government to the sector, they are still facing myriads of problems. Among the many problems faced by the MSMEs, financial management problem is one serious problem which cannot be neglected as the success and failure of the enterprises depend largely on how efficiently they manage their finance. A need to properly look after the finance of the business and to see if they are properly managed is important.

The study therefore seeks to determine the financial management practices followed by the Micro and Small Enterprises in Manipur. The study will also help in identifying the various flaws and problems faced by the entrepreneurs in their financial management work and suggest means of overcoming the difficulties and problems. This will therefore help the sector in taking steps to better equip themselves with the appropriate tools for the efficient management of their financial affairs which will ultimately lead to the success of their business.

\section{REVIEW OF LITERATURE}

Various studies have been made regarding the problems faced by the MSMEs in different parts of the country. However, there are still very few researches related to the financial management 
problem faced by the Micro and Small Enterprises. Also, no research work has been done in Manipur regarding the financial management practices followed by the MSEs in Manipur.

Ravi (2012) in his study stated that financial management plays a very important role in the survival, growth and development of the small-scale industries. The study further stated that finance is the key input for the sustained growth of the small-scale industries and financial management is the key strategy to achieve this growth.

Raju (2015) in his study regarding the Financial management practices of the Micro and Small Enterprises in Kerala found out that the financial management practices followed by the MSEs are only firefighting in nature and are learned basically through experience which shows their lack of knowledge regarding the proper financial management of their enterprise.

Hendrik \& Quentin (2015) made a study aiming to find the financial management skills necessary for the success of the small and medium enterprises. Among the various financial management practices, the study found out that working capital management and profitability management are very important factor to be kept into consideration for the successful operation of the business enterprises.

Ahmad and Sanu (2016) in their study tried to find out the role of MSMEs in the inclusive growth of the economy and also highlights the significant contribution of MSMEs to the Indian economy in terms of industrial production, exports and other economic indicators. The study found out that the MSME sector is promoting inclusive growth in India by means of creating large scale employment opportunities, scaling down regional disparities and bringing backward classes of the people into the main stream of the economy.

Gawali and Gadekar (2017) made a study highlighting the significance of better financial management decisions on the basis of efficient financial management practices which are critical and crucial for the survival, growth and profitability of MSMEs. The study concluded that accounting and financial knowledge of the management and their management in the financial affairs of the business helps to a great extent in the success of the business.

Uddin, Biswas, Ali and Khatun (2017) in their study showed that the level of awareness on the importance of Financial Management and accounting system is still very low in SMEs and most managers are not aware of the importance of accounting records. The study also found that in order to keep constant development stable, entrepreneurs need to follow accounting in enterprise and suggested that educating managers and owners on the need to keep accounting record is the best solution.
Ratan, Rajkumar and Meetei (2019) in their study tries to identify the strategical constraints hindering the growth and development of MSMEs in Manipur. The study found out that MSMEs are not able to grow up to the expected level because of problems like lack of financial assistance from the financial institutions, lack of professional and managerial skills, lack of establishing proper contacts, lack of knowledge to establish the business in an organised and structured way. Though the volume of production of the MSME is very large, the qualities of production, diversification of products, energy consumption and environmental effect have always been a concern.

Naveen S \& Nagaraju Y (2019) made a study with the objective of accessing the performance and contribution of MSMEs to the Indian as well as global economy. The study found that MSME serve as a catalyst for the even distribution of development and wealth in the country. The study findings indicated that MSMEs engaging in trade activities dominates the industry. The study found that $51 \%$ of the MSMEs are in rural areas and $49 \%$ in the urban areas. MSME contributes between $40-50 \%$ of India's total export. The average contribution of MSME to the GDP is $30 \%$ and to the GVA is $32 \%$. MSME contribute about $40 \%$ of the total employment, out of which $55 \%$ are in Urban areas and $76 \%$ of them are male.

\section{OBJECTIVES OF THE STUDY}

The study is done with the main objective of finding out the financial management practices adopted by the Micro and Small Enterprises in Manipur. The specific objectives of the study are listed hereunder:

1) To find out the Financial Management practices of the Micro and Small Enterprises in Manipur.

2) To increase awareness about the importance of Financial management in a business.

3) To find out the problems faced by the MSEs while maintaining their accounts and managing their finance.

4) To suggest means of solving the problems faced by the sample enterprises.

\section{METHODOLOGY}

The present study is made by using both primary and secondary data. At first, the available related articles, books, journals, government's periodical and reports, annual report, etc. were used to extract the required information regarding the Micro and Small Enterprises. At the later stage, primary data were collected from 90 enterprises using structured questionnaire prepared by the researcher. The primary data collected using the structured questionnaire were analysed using various statistical tools keeping the objectives in mind. 


\section{LIMITATIONS OF THE STUDY}

The various limitations of the study are listed below:

1) Some of the micro and small enterprises do not maintain any written records at all.

2) Some enterprises do not want to disclose their information to outsiders for fear of disclosure.

\section{PROFILE OF THE ENTERPRISE}

The profile of the enterprise that have been considered under the study is presented in Table 1. It can be seen from the study that $96.67 \%$ of the enterprises are Micro enterprise and only $3.33 \%$ are Small scale enterprise. Among these enterprise majority $(73.33 \%)$ of them are engaged in rendering service and only $26.67 \%$ units are manufacturing products. Among the 90 units, $93.33 \%$ are soleproprietorship and only $6.67 \%$ are partnership owned. 39 units out of the total are engaged in producing or rendering service of some types, 12 units are electronics, 15 units hardware, 12 units in pharmaceuticals, 6 units are in tailoring and 3 unit each in producing food items and handloom. The Table shows that $20 \%$ of them are uneducated, $26.67 \%$ of them received education till matriculate, $16.67 \%$ of them are under graduate, $26.67 \%$ of them are graduate and $10 \%$ of them have finished their post-graduation. Among these units, $36.67 \%$ of the units are in existence for a period of more than 10 years, $10 \%$ of the units existed for more than 20 years, $20 \%$ of them are in existence for about five years while $33.33 \%$ of them existed for more than 5 years.

Table 1: Profile of the enterprises and entrepreneurs

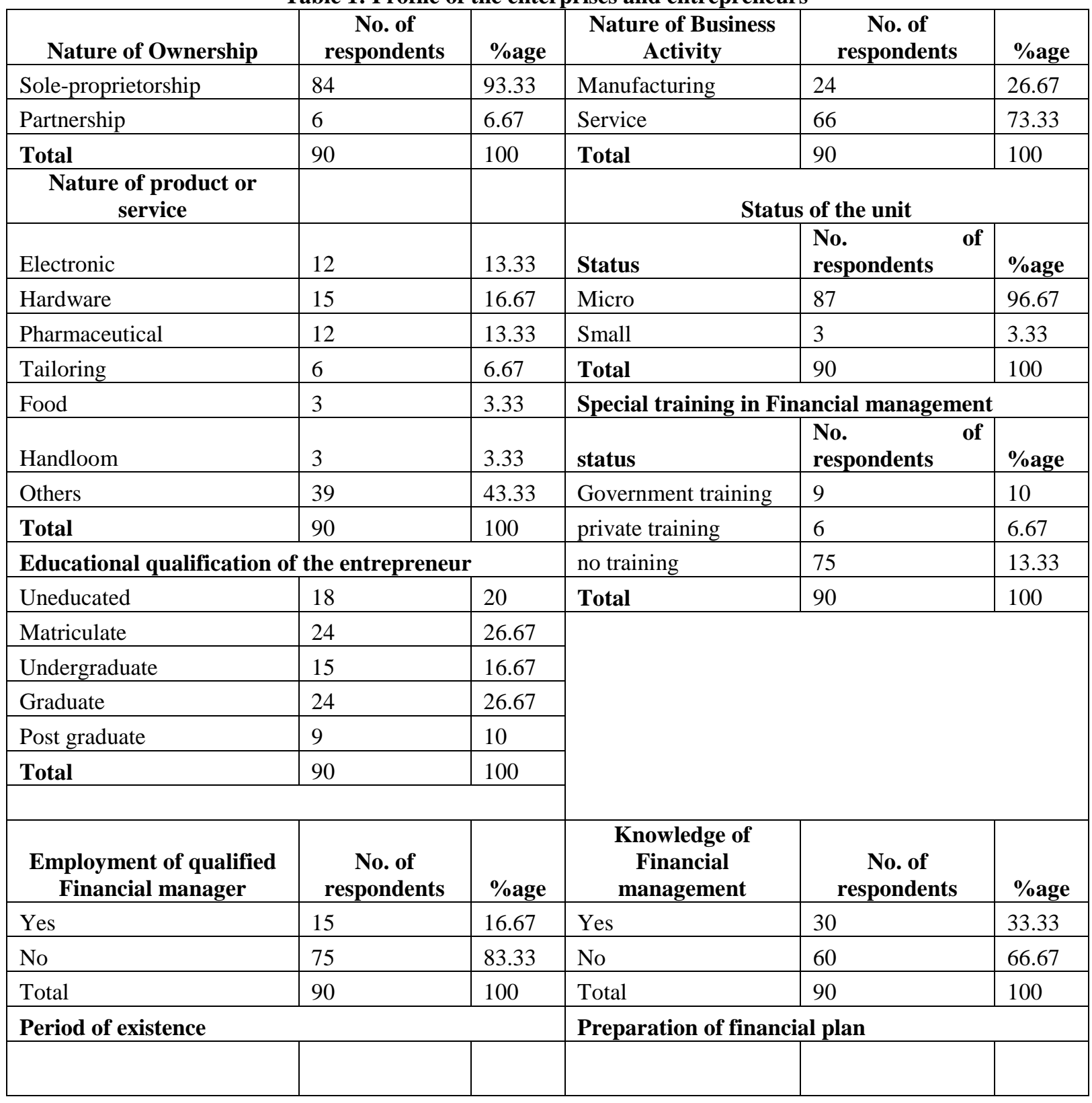




\begin{tabular}{|l|l|l|l|l|l|}
\hline \multicolumn{1}{|c|}{ Years } & $\begin{array}{c}\text { No. of } \\
\text { respondents }\end{array}$ & \%age & \multicolumn{1}{|c|}{ status } & \multicolumn{1}{c|}{$\begin{array}{c}\text { No. of } \\
\text { respondents }\end{array}$} & \%age \\
\hline Up to 5 years & 18 & 20 & long term & 21 & 23.33 \\
\hline 6-10 years & 30 & 33.33 & medium term & 9 & 10 \\
\hline 11-20 years & 33 & 36.67 & short term & 3 & 3.33 \\
\hline More than 20 years & 6 & 10 & No plan & 57 & 63.33 \\
\hline Total & 90 & 100 & Total & 90 & 100 \\
\hline
\end{tabular}

FINANCIAL MANAGEMENT \& ACCOUNTING

\begin{tabular}{|c|c|c|}
\hline \multicolumn{3}{|c|}{ Knowledge of Financial management } \\
\hline & No. of respondents & \%age \\
\hline Yes & 30 & 33.33 \\
\hline No & 60 & 66.67 \\
\hline Total & 90 & 100 \\
\hline \multicolumn{3}{|c|}{ Employment of qualified Financial manager } \\
\hline & No. of respondent & \%age \\
\hline Yes & 15 & 16.67 \\
\hline No & 75 & 83.33 \\
\hline Total & 90 & 100 \\
\hline
\end{tabular}

\begin{tabular}{|c|c|c|}
\hline \multicolumn{3}{|c|}{ Special training in Financial management } \\
\hline Status & $\begin{array}{c}\text { No. of } \\
\text { respondents }\end{array}$ & \%age \\
\hline $\begin{array}{c}\text { Government } \\
\text { training }\end{array}$ & 9 & 10 \\
\hline Private training & 6 & 6.67 \\
\hline No training & 75 & 13.33 \\
\hline Total & 90 & 100 \\
\hline
\end{tabular}

$33.33 \%$ of the owner/manager of the MSEs does not have any knowledge of financial management while $66.67 \%$ of them have some knowledge of financial management. 16.67 of the enterprises employ a financial manager while $83.33 \%$ of the enterprises does not employ any a financial manager. Out of the

total, 75 of the owners /managers do not receive any form of training in financial management, while 9 of them receive training from the government and 6 of them receive training from private institutes or training centres.

\section{Capital Structure}

\begin{tabular}{|c|c|c|}
\hline \multicolumn{3}{|c|}{ Source of Capital } \\
\hline Source of Capital & No. of respondents & \%age \\
\hline Owned fund & 57 & 63.33 \\
\hline Borrowed fund & 24 & 26.67 \\
\hline Both owned and borrowed & 0 & 0 \\
\hline Bank loans & 9 & 10 \\
\hline Total & 90 & 100 \\
\hline \multicolumn{3}{|c|}{ Working capital requirement } \\
\hline Working capital amount & No. of respondents & \%age \\
\hline up to 50,00 & 30 & 33.33 \\
\hline $50,001-2,00,000$ & 24 & 26.67 \\
\hline $2,00001-10,00,000$ & 15 & 16.67 \\
\hline $10,00,001-25,00,000$ & 0 & 0 \\
\hline above $25,00,000$ & 6 & 6.67 \\
\hline no working capital & 15 & 16.67 \\
\hline Total & 90 & 100 \\
\hline \multicolumn{3}{|c|}{ Financing of Working capital } \\
\hline Type of financing & No. of respondents & \%age \\
\hline Owned fund & 51 & 68 \\
\hline Borrowed fund & 9 & 12 \\
\hline
\end{tabular}




\begin{tabular}{|c|c|c|}
\hline Both owned \& borrowed & 15 & 20 \\
\hline Total & 75 & 100 \\
\hline \multicolumn{2}{|c|}{ Method of working capital estimation } \\
\hline Method of estimation & No. of respondents & \% age \\
\hline Through past experience & 18 & 24 \\
\hline By estimating C.A. \& C.L. & 33 & 44 \\
\hline No formal estimation & 24 & 32 \\
\hline Total & 75 & 100 \\
\hline
\end{tabular}

$63.33 \%$ use their owned funds to finance and start their business. $26.67 \%$ of them used borrowed funds from friends and relatives and only $10 \%$ of them took loans from banks to start their business. $33.33 \%$ of the enterprises need working capital up to Rs. 50,000, $26.67 \%$ need working capital between Rs. 50,001$2,00,000,16.67 \%$ need Rs. 2,00,001-10,00,000, $6.67 \%$ need above Rs. 25,00,000 and $16.67 \%$ keep no working capital. When asked about the sources of their working capital, $68 \%$ of them used their owned funds, $12 \%$ of them use borrowed funds while $20 \%$ of them used both owned and borrowed funds. $24 \%$ of them estimated their working capital needs using their past experience, 44\% used the method of comparing Current assets and Current liabilities and $32 \%$ of them use no formal estimation.

Purchase Management

\begin{tabular}{|c|c|c|c|c|}
\hline \multicolumn{4}{|c|}{ Frequency of purchase } & \\
\hline Frequency & \multicolumn{2}{|c|}{ No. of respondents } & $\%$ age & \\
\hline Daily & \multicolumn{2}{|r|}{3} & 3.33 & \\
\hline Weekly & \multicolumn{2}{|r|}{27} & 30 & \\
\hline Monthly & \multicolumn{2}{|r|}{9} & 10 & \\
\hline Whenever required & \multicolumn{2}{|r|}{51} & 56.67 & \\
\hline Total & \multicolumn{2}{|r|}{90} & 100 & \\
\hline \multicolumn{4}{|c|}{ Proportion of credit purchase } & \\
\hline \multicolumn{2}{|c|}{ Proportion of credit purchase } & \multicolumn{2}{|c|}{ No. of respondents } & \%age \\
\hline \multicolumn{2}{|l|}{ up to $10 \%$} & \multicolumn{2}{|c|}{3} & 3.33 \\
\hline \multicolumn{2}{|l|}{$10-20 \%$} & \multicolumn{2}{|c|}{27} & 30 \\
\hline \multicolumn{2}{|l|}{$20-30 \%$} & \multicolumn{2}{|c|}{21} & 23.33 \\
\hline \multicolumn{2}{|l|}{ above $30 \%$} & \multicolumn{2}{|c|}{6} & 6.67 \\
\hline \multicolumn{2}{|l|}{ cash only } & \multicolumn{2}{|c|}{33} & 36.67 \\
\hline \multicolumn{2}{|l|}{ Total } & \multicolumn{2}{|c|}{90} & 100 \\
\hline \multicolumn{4}{|c|}{ Average payment period } & \\
\hline Frequency & \multicolumn{3}{|c|}{ No. of respondents } & \%age \\
\hline Daily & \multicolumn{3}{|c|}{9} & 10 \\
\hline Weekly & \multicolumn{3}{|c|}{18} & 20 \\
\hline Monthly & \multicolumn{3}{|c|}{27} & 30 \\
\hline No time bound & \multicolumn{3}{|c|}{36} & 40 \\
\hline Total & \multicolumn{3}{|c|}{90} & 100 \\
\hline
\end{tabular}

Only $3.33 \%$ of the enterprise make their required purchase on a daily basis, $30 \%$ of them purchase weekly, $10 \%$ of them monthly and $56.67 \%$ of them made purchase whenever required. Again 3.33\% made credit purchase up to $10 \%, 30 \%$ of them made $10-20 \%$ of their purchase on credit, $23.33 \%$ of the enterprise take credit between $20-30 \%, 6.67 \%$ took credit above $30 \%$ while $36.67 \%$ of them made only cash purchase. $10 \%$ of the enterprises made their payment on a daily basis, $20 \%$ paid weekly, $30 \%$ paid monthly and $40 \%$ have no fixed time bound for paying back their debts. $6.67 \%$ of the enterprises made daily collection of dues, $3.33 \%$ collects weekly, $16.67 \%$ collects monthly and $73.33 \%$ have no specified time period. 
Cash Management

\begin{tabular}{|c|c|c|}
\hline \multicolumn{3}{|c|}{ Average amount of cash kept in Business } \\
\hline Average cash kept & No. of respondents & \% age \\
\hline up to Rs. 10,000 & 27 & 30 \\
\hline $\mathbf{1 0 , 0 0 1 - 5 0 , 0 0 0}$ & 12 & 13.33 \\
\hline $\mathbf{5 0 , 0 0 1 - 1 0 0 , 0 0 0}$ & 6 & 6.67 \\
\hline above 100,000 & 3 & 3.33 \\
\hline No cash kept & 42 & 46.67 \\
\hline Total Preparation of financial plan & 100 \\
\hline Status & No. of respondents & $\%$ age \\
\hline long term & 21 & 23.33 \\
\hline medium term & 9 & 10 \\
\hline short term & 3 & 3.33 \\
\hline No plan & 57 & 63.33 \\
\hline Total & 90 & 100 \\
\hline
\end{tabular}

\begin{tabular}{|c|c|c|}
\hline \multicolumn{3}{|c|}{ Preparation of Cash Budget } \\
\hline Period & No. of respondents & \%age \\
\hline One month & 15 & 16.67 \\
\hline Two months & 0 & 0 \\
\hline 3 months & 3 & 3.33 \\
\hline No cash budget & 72 & 80 \\
\hline Total & 90 & 100 \\
\hline
\end{tabular}

$30 \%$ of the enterprises kept cash up to Rs.10,000, $13.33 \%$ kept Rs.10,001-50,000, $6.67 \%$ of them kept Rs.50,001-100,000, 3.33\% kept above Rs.100,000 cash in their business, while $46.67 \%$ of the enterprises did not kept any cash. When asked about

Profit and uses of profit of the Business

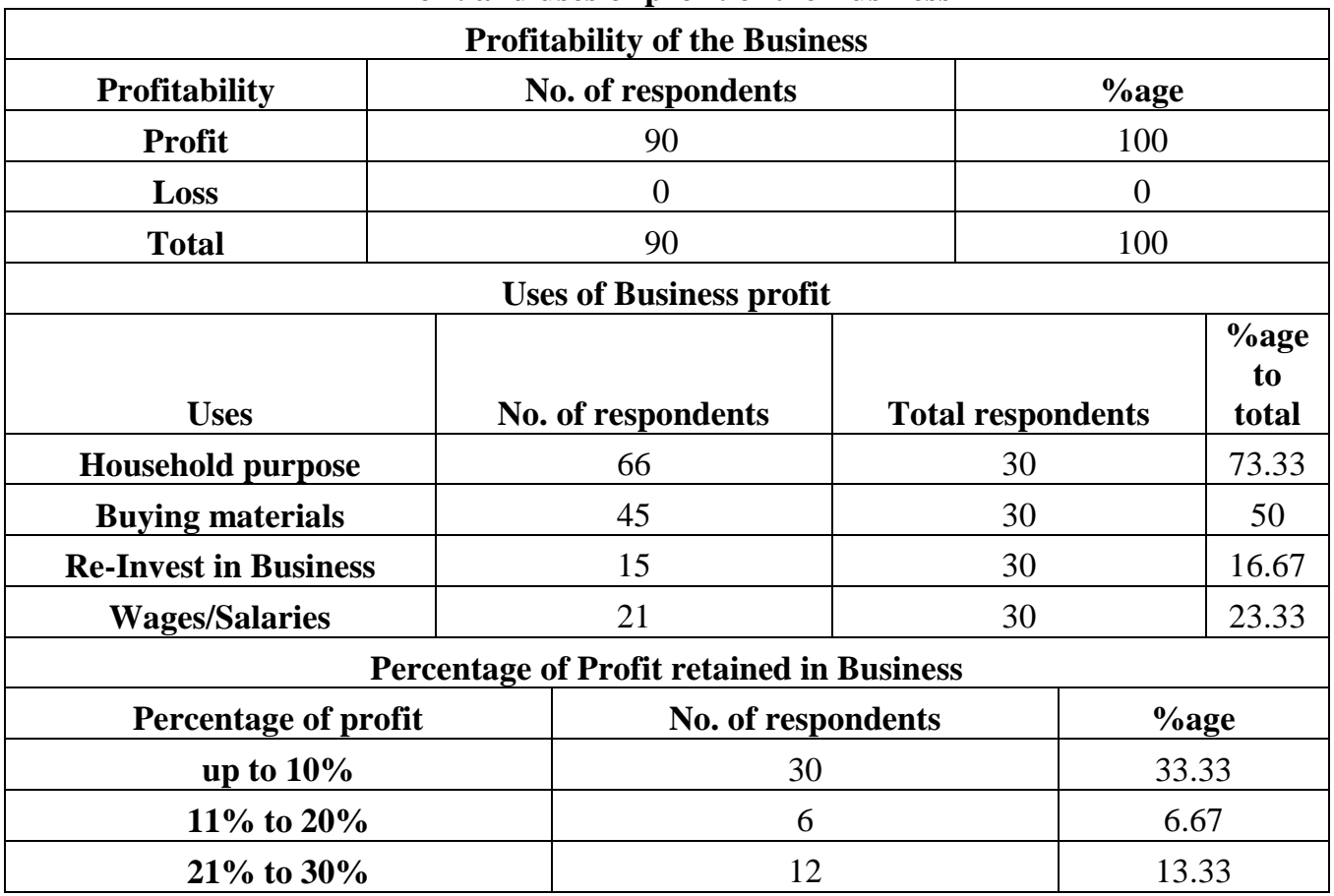

(c) 2021 EPRA JEBR | EPRA International Journal of Economic and Business Review I www eprajournals.com 


\begin{tabular}{|c|c|c|}
\hline Above 30\% & 3 & 3.33 \\
\hline No profit retained & 39 & 43.33 \\
\hline Total & 90 & 100 \\
\hline
\end{tabular}

$100 \%$ of the sampled enterprises earn profit. $73.33 \%$ of the enterprises use their profit for their household expenses, $50 \%$ of them used it to buy back the needed materials for their business, $16.67 \%$ of them re-invest and $23.33 \%$ of the enterprises use it for the payment of wages and salaries. $33.33 \%$ of the enterprises retained up to $10 \%$ of their profit in their business, $6.67 \%$ retained up to $20 \%, 13.33 \%$ retain up to $30 \%, 3.33 \%$ retained above $30 \%$ of their profit and $43.33 \%$ does not use retained earnings.

Preparation and use of financial statement

\begin{tabular}{|c|c|c|c|}
\hline \multicolumn{4}{|c|}{ Preparation of financial statement } \\
\hline Type & No. of respondents & Total & \%age to total \\
\hline trading \& P/L & 21 & 30 & 23.33 \\
\hline B/S & 30 & 30 & 30 \\
\hline CFS & 30 & 30 & 30 \\
\hline WCS & 12 & 30 & 13.33 \\
\hline Budget & 9 & 30 & 10 \\
\hline Business preparing no FS & 48 & 30 & 53.33 \\
\hline
\end{tabular}

$23.33 \%$ of the enterprise prepares Trading and Profit/Loss account, 30\% prepare Balance Sheet, Cash Flow Statement and Budget for their business, $13.33 \%$ prepares Working Capital Statement and $53.33 \%$ does not prepare any financial statement.

\section{SUGGESTION}

1. Majority of the sampled enterprises does not use any form of borrowed funds or loans of any kind for investment in their business which deprived them of the advantage of leveraging.

2. A proper system of working capital estimation is very much needed for these enterprises as majority of them do not employ any formal method.

3. Almost half of the enterprises do not keep any ready cash for their business and many of them also does not maintain proper working capital which are very important components to the business.

4. Many enterprises do not have specified time period for the collection and payment of dues which will be a problem since the true position of the business cannot be known without them.

5. More than half of the enterprises does not prepare any form of financial statement of their business. Financial statements which shows the position, profitability, liquidity, stability, etc. of the business needs to be properly maintained.

6. Majority of the enterprises neither have any formal training regarding the proper management of finance and preparation of accounts. Training should be provided to these enterprises.

\section{CONCLUSIONS}

It has already become a common knowledge that Micro and Small Enterprises are the backbone of the economy. They provide employment opportunities, thereby, solving the problems of unemployment. The sector has also contributed a lot in terms of GDP, export, production, etc. MSEs also help to increase the standard of living of the country and also remove the problems of migration from rural to urban areas. For the purpose of this study, a sample questionnaire was formed which was distributed to the targeted sampled enterprises. The data collected were tabulated and then analysed. It was found out from the study that many of the owner/manager of these enterprises still does not have any knowledge of financial management and its importance for their business. The financial management system followed by these enterprises are only firefighting in nature. Many of the owner/manager use their experience as a tool for recording as well as management of their accounts. They also do not have any formal estimation of working capital nor prepare financial plans and budgets. Many of the enterprises do not have proper debt collection and payment system. There is a need to develop a proper system of financial management and accounting record for the micro and small enterprises of Manipur.

\section{REFERENCES}

1. Firdos Ahmad \& Sahnewaz Sanu. MSMEs and Inclusive Growth in India: Current Scenario and Future Prospective. Intellection: A Bi-annual 
Interdisciplinary Research Journal, July December, 2016 Vol. IV, No. II ISSN: 2319-8192.

2. Hendrik Wolmarans \& Quentin Meintjes. Financial management practices in successful smack and medium enterprises (SME). SAJESBM Volume 7 (2015).

3. Kwadwo Boateng, Naveen Sodem \& Nagaraju $Y$. (2019). The Contribution of MSMEs to the Growth of the Indian and Global Economy, International Journal of Multidisciplinary, Volume 4, Issue 3, March. ISSN: 2455-3085 (Online) - www.rrjournals.com [UGC Listed Journal]

4. Raju. G. A study on the financial management practices of Micro and Small Enterprises in Kerala. Project Report. Kerala Institute of Labour and Employment, Thiruvananthapuram.

5. Ravi N. Kadam. Financial management: The key strategy for the sustained growth of Small-scale Industries of India. International Journal of Research in Finance \& Marketing. Volume 2, Issue 2 (February 2012) (ISSN 2231-5985)

6. Ravindra B. Gawali \& Ashutosh Gadekar. Financial Management Practices in Micro, Small and Medium Enterprises-An Exploratory Analysis with the help of Literature Review. International Journal of Research in Finance and Marketing (IJRFM) Available online at: http://euroasiapub.org/current.php?title $=I J R F M$ Vol. 7 Issue 6, June - 2017, pp. 45 59 ISSN(o): 2231-5985 | Impact Factor: 6.397 | Thomson Reuters Researcher ID: L-5236-2015.

7. Sharma, A Ratan Kumar, Rajkumar M. and Meetei K. I. (2019). MSMEs in Manipur with respect to Strategic Constraints: A review, International Journal of Research and Analytical Reviews (IJRAR), Volume 6, Issue 2, May 2019. www.ijrar.org (E-ISSN 2348-1269, P- ISSN 2349-5138).

8. Uddin, R., Biswas, T., Ali, J. and Khatun M. S. Accounting practices of SMEs in Rangpur, Bangladesh. Journal of Business and Financial Management Vol.6 Issue4, 2017 doi:10.5172/2167-0234.1000299 